Londoners or a circular parkway. But it was in the 1930s when Middlesex was disappearing at unprecedented speed beneath bricks and mortar that ideas gave way to action. A sense of urgency was added by the publication of figures about the shortage of playing fields within London and the rate at which potential parkland was being dovoloped on the fringes of the city. These gave strength to Raymond Unwin's 1933 proposal for a thin green girdle which found its political destiny in the London County Council's first Tabour administration in 1934. Money to buy open fields and then a special Act of Parliament to protect them appeared during the next four years.

The green belt of today sterns from the more extensive one proposed by Abercrombic in 1944. It was given statutory backing between 1954 and 1958, but no sooner had this happened than the Home Counties, ever fearful of London's urban hordes, proposed extending it to cover 2,000 square miles.

Dr Thomas sets out to considor how London might have grown without a green belt but says that there is insufficient evidence on which to theorize. He contents himself with a statistical description of land uso changes in the belt and then another one of all the land, urban and rural, in a 10 mile ring around built-up London.

These analyses throw interesting light on things such as the uneven distribution of recreation land, nearly twice as much to the south-west as to the south-east, and on the great extent of the towns set in the green belt to the west of London. Questions about the future of the belt, whether it has impeded London's dynamic, whother it should be turned into a chain of new Royal Parks dotted about with weckend cottages for Londoners, are hinted at but not explored. Dr Thomas leaves the answering of them to the policy makers, which is a pity, but ho has provided a useful base from which to start.

Terence Bendixson

\section{PRESSURES ON THE COUNTRYSIDE}

\section{People and the Countryside}

By H. E. Bracey. Pp. $x x+310+8$ plates. (Routledge and Kegan Paul: London, March 1970.) $63 s$.

DR BRACEY has written a comprehensive survey of man's influence on landscape, ranging from the earliest trackways along the chalk uplands to the modern nature trail, from the struggles of a small population to clear forests for agriculture to the demands of a huge population for recrcation. Careful scientific studies of the problem of the invasion of the countryside are comparatively recent. How many tramping feet will destroy the marram grass on sand dunes? What measures can be taken to reduce erosion? What steps can be taken to lessen the impact of too many people watching too little wild life ? Bracey gives well documented accounts of research on these, now burning, questions.

Bracey looks at overy aspect of the countryside, workwise as well as playwise, the repercussions of new industry, railways, bus services, local government and, of course, the effect of new roads and traffic. The internal combustion engine is bringing greater changes to the landscape and the countryside than anything which has happened in all the centuries which Bracey surveys. The straightening and widening of roads, the building of by-passes and car parks, are profoundly affecting our land, and it is essential that some ovorall policy should be adopted, essential that at some stage road engineers should stop, at least in places such as the National Parks and Areas of Outstanding Natural Beauty, if the character of these is not to be completely changed. Bracey says rather less on this subject, and on the possibilitios of traffic management (such as the Goyt Valley scheme), than might have been expected.
There are chaptcrs on dereliction and litter; on the problems of water supply, including the use of reservoirs for recreation; on common land, its present and future use; on the increasing rolo of forests in providing facilities for recreation, and there is comment on the large part the Forestry Commission has played in pioneering this use. Every chapter is followed by comprehensive notes giving the sources of information. There is, in addition, as an appendix, a list of further reading.

This is a book, as tho author himself says, for the thoughtful citizen who sees changes coming rapidly to the countryside and wishes to know what is being, and what can be, done about it. It is also a book for the student and teacher, providing a firm and adequate basis for further research. Bracey's practice of enumerating his points, which he does throughout the book, makes for an easy assessment of the problems, which can then be pursued in more detail. It is a book also for all those concerned with the countryside, planner, forester, water engineer, those in local government and those concerned with leisure. It is certainly a book which should be on many bookshelves; it will, after the initial perusal, be frequently required for reference.

\section{Geoferey Berry}

\section{HISTORY OF BRITISH PLANTS}

Studies in the Vegetational History of the British Isles Edited by D. Walker and R. G. West. (Essays in Honour of Harry Godwin.) Pp. 266. (Cambridge University Press: London, April 1970.) 160s; \$25.

THIs is a book of eleven essays written by thirteen people, all of whom were at some time associated with the subdepartment of Quaternary research in the botany school at the University of Cambridge. The collection is published to mark the retirement from the chair of botany at Cambridge of Professor Harry Godwin, who founded the sub-department and was for many years its inspiration and director. Most of the contributions directly reflect Professor Godwin's own spccial interests, although it may truly be claimed that it would be difficult to find an aspect of Quaternary research which had not been at some time the subject of original contributions by Professor Godwin himself.

Mention should perhaps first be made of the essay by Professor D. Walker on estimates of rate of change in autogenic hydroseres and of the use by Professor F. Oldficld of evidence from stratigraphical and pollen analyses to investigate the ecological relationships of vegetation at Blelham Bog, because both these contributions recall Professor Godwin's original work in plant ecology and particularly in the ecology of bog and fen. Similarly, Dr J. J. Donner's essay on changes in the relative levels of land and sea in Scotland recalls Professor Godwin's papers on the same problems around the coasts of England and Wales.

The book contains such a wide variety of interests that a short review must unavoidably be superficial or selective. The first essay, by R. G. West, provides a very concise but valuable summary of the history of British vegetation throughout the whole Pleistocene period. It emphasizes the enormous quantity of information that is now available and yet the comparative lack of knowledge of regional variation in all phases earlier than the Late Weichselian and Flandrian, as we must now call the Late and Postglacial periods.

Mrs T. G. 'Tutin's contribution is also a masterly review and summary of a large arnount of information from the English Lake District from which there are now available pollen-diagrams from sixty sites. It must be hoped this will inspire others to write regional summaries. Dr A. G. Smith discusses evidence that Mesolithic man had a 